инженерного образования в мировое образовательное пространство, - нельзя не видеть, что высшая техническая школа страны в 1990-е гг. развивалась в условиях системного кризиса, недофинансирования, отсутствия научно-обоснованной программы, государственной поддержки. Государственная политика и в этой сфере отличалась непоследовательностью и хронической нереализованностью намеченного. Проведенное исследование и иные, опубликованные нами данные[12,13], позволяют констатировать игнорирование со стороны органов исполнительной власти требований и предложений вузовской общественности, пренебрежение к сложившимися в отечественной высшей школе традициям. Единственной значимой, на наш взгляд, победой научнопедагогической общественности явилась остановка процесса приватизации учреждений научной и образовательной сферы. Оезкое сокращение финансирования научнотехнической сферы и инженерного образования было связано не только с кризисными процессами в экономике. Оно обосновывалось теоретически.

$$
* * *
$$

1. Государственный архив Российской Федерации Ф. 10265. Оп.1. Д. 55. Л.263-264.

2. ГАРФ Ф. 10265. Оп. 1 Д.55. Л. 143.

3. ГАРФ Ф. 10265 . Оп. 1 Д.55. Л.143

4. ГАРФ Ф. 10265. Оп.1. Д. 57. Л.46-55.

5. ГАРФ Ф. 10265. Оп.1. Д. 57. Л. 219.

6. ГАРФ Ф. 10265. Оп. 1. Д. 57. Л.191.

7. ГАРФ Ф. 10265. Оп. 1. Д. 57. Л. 192.

8. ГАРФ Ф. 10265. Оп. 1. Д. 57. Л.193.

9. ГАРФ Ф. 10265. Оп. 1. Д. 57. Л. 204.

10. ГАРФ Ф. 10265. Оп. 1. Д. 57. Л.207.

11. Архив Государственной Думы Федерального Собрания РФ. Ф. 10100. Оп. 15 п-ІІІ. Д. 39. Л. 152.

12. Bodrova E. V., Kalinov V.V.Reformation of the Scientific and Technical Sphere in the Russian Federation in the "Transition Period": Plans and Reality in 1990s// Journal of History Culture and Art Research 6(5) (Special Issue on Russian Studies) Tarih Kültür ve Sanat Araştırmaları Dergisi ANA SAYFA > Cilt 6, Sayı 5 (2017) P.192-199// [Электронный pecypc ] URL: http://kutaksam.karabuk.edu.tr/index.php/ilk/issue/view/31 (дата обращения 03.01.2018)

13. Бодрова Е.В., Голованов Н.Б. Модернизация высшей технической школы: исторический опыт и современность// Российский технологический журнал. М. Московский технологический университет. 2017 Т. 5.№.6. С.73-97.

\title{
Гурин В.В. \\ Сюжетный уличный краеведческий квест: опыт разработки и проведения в г. Томске
}

Томский государственный педагогический университет (Россия, Томск)

doi:10.18411/spc-10-01-2018-10

idsp: 000001:spc-10-01-2018-10

\section{Аннотация}

Автор статьи делится опытом создания и проведения уличных квестов в г. Томске. В статье излагаются проблемы такого рода деятельности и возможные пути их решения, а так же соображения на счет перспектив коммерческого запуска уличных квестов.

Ключевые слова: уличные квесты, экскурсии, Живой город, игра.

\section{Annotation}

The author shares the experience of creating and conducting street quests in Tomsk. The article outlines the problems of this kind of activity and possible solutions to them, as well as considerations on the prospects of commercial launch of street quests.

Key words: street quests, excursions, game, Living city. 
Среди форм организации свободного времени горожан в последнее время все большую популярность приобретают уличные (или живые) квесты. Такие квесты можно отнести к синтезированным формам досуга, позволяющим решать сразу несколько задач: познавательных, коммуникационных, развлекательных, а также заставляющих участников ориентироваться на здоровый образ жизни - двигаться, бегать, гулять по родному городу. Если в городах-миллионниках обычно уже созданы крупные центры по организации уличных квестов, то в небольших городах России это движение только разворачивается. В связи с этим становится актуальной специфика организации таких досуговых форм в небольших городах, в частности в г. Томске.

Цель данной статьи: поделиться практическим опытом по созданию и организации уличных квестов на базе мастерской квестов «Живой город», работающей в г. Томске. Под «уличным квестом» мы понимаем игру, в которой участники с целью найти ответ на главный вопрос игрового сюжета (выполнить цель игры) перемещаются по городским локациям и проходят оставленные организаторами задания и головоломки. Несмотря на популярность квестов в комнатах (или «реалити-квестов»), наш выбор в пользу уличного формата был не случайным. Во-первых, проведение уличных квестов само по себе не требует больших затрат и ресурсов, во-вторых, они проходят на свежем воздухе, дают простор и живую наглядность. Последнее обстоятельство позволят им заменять привычные форматы экскурсий по городу, при условии построения квеста на экскурсионном материале [1], о чем будет намечено ниже.

Приступая к работе над квестами, мы уже имели дело с созданием игровых моделей. Речь идет о частой работе в детских лагерях, сопряженной с разработкой и проведением различных игр, анализа результатов. Это упрощало задачу и летом 2017 г. мы взялись за создание уличных квестов в г. Томске. Его более чем 400-летняя история богата событиями и интересными людьми, поэтому квесты решено было моделировать с экскурсионным уклоном. Такие «дидактические квесты» по нашей задумке должны были, с одной стороны, быть полезны с экскурсионной точки зрения, донося людям информацию об истории Томска, с другой - являться для людей «интеллектуальным развлечением». Кроме того, уличные квесты являются необычным форматом социальных развлечений, способных в век компьютеров и социальных сетей возрождать интерес детей и взрослых к живому игровому взаимодействию [2].

Основной сложностью, с которой мы столкнулись на первых этапах создания квеста, являлось написание интересного сюжета, чаще всего детективного. Редко его можно позаимствовать из истории в готовом виде, поэтому обычно он строится на переплетении реальных лиц или событий с вымышленными. Следом создается система головоломок, решая которые участники будут перемещаться по карте и собирать части сюжетной мозаики в единый пазл. Чем органичнее головоломки будут вписываться в сюжет, тем более интересным будет прохождение квеста.

Одним из самых существенных минусов уличных или городских квестов является их зависимость от погоды и времени года. Поэтому, проработав несколько месяцев, мы вынуждены были с холодами уйти на сезонные каникулы. За это время мы успели выпустить 4 квеста: «Золотая лихорадка», «Знак семерых», «Человек со шрамом», «Команда «Земля»», последний из которых создан специально для детей.

Пилотного запуска проекта было достаточно, чтобы понять основные проблемы и перспективы такого рода деятельности. Разберемся в них по порядку. При проведении уличного квеста существует вероятность пропажи какой-либо спрятанной информации из-за любопытства случайных прохожих (как правило, детей) или проходящего рядом другого квеста, участники которого могут найти и принять ваш тайник за свой. Во время игр мы попадали в обе неприятные ситуации, и пришли к необходимости создания запасных материалов, которые при необходимости 
игротехник раздаст участникам взамен пропавших. Внутренняя организация квеста должна учитывать разные типы игроков. Некоторых больше привлекает не командная работа и вдумчивое изучение сюжета игры, а индивидуальное прохождение самих головоломок. Иногда такие игроки могут забегать вперед, досрочно проходя все головоломки (игнорируя сюжет игры) и лишая удовольствия от поиска остальных. Поэтому желательно подобрать головоломки так, чтобы они исключали свое прохождение в отрыве от сюжета игры или же закрепляли необходимость коллективного решения. Еще одна проблема, с которой сталкиваешься при организации квеста: игроки могут случайно, преждевременно найти информацию, которая предназначалась для них позже. Такая находка грозит путаницей или досрочным окончанием квеста, поэтому ее вероятность нужно исключить или обезвредить последствия, сделав случайную находку до поры бесполезной.

Подбор игровых локаций также является значимой частью подготовки квеста. У игроков должно быть четкое понимание границ игрового мира (дабы избежать их ухода в другие места), при этом игра для них должна быть психологически комфортной. Помочь в этом может карта или иное указание на игровые границы. Важную роль играет не только выгодное расположение игровой локации (наличие в пределах игровой зоны подходящих мест для оборудования тайников), но и протяженность. Слишком большая, она ведет к чрезмерному уставанию игроков от перемещения и потере игрового интереса, слишком маленькая - к игровой ограниченности и возрастанию риска преждевременных находок, о котором было замечено выше. Если при выборе места игры, достаточно предварительной разведки с осмотром потенциальных локаций, то при выборе протяженности игрового пространства «на глаз» можно не угадать. Установить его правильно можно только опытным путем, проверив квест в тестовом режиме на одной-двух командах. Отдельно стоит оговориться о безопасности участников квеста, для чего нужно с умом выбирать игровое пространство. Например, если квест проходят несовершеннолетние, стоит напомнить о правилах безопасности дорожного движения (при наличии такого на карте игры) и проч. [3].

Bсе вышеописанное мы устанавливали опытным путем, участь на своих ошибках. Надеемся, что начинающие организаторы квестов, после прочтения данного материала, смогут избежать их повторения.

Для коммерческого запуска проекта недостаточно просто делать хорошие квесты, нужно уметь продвигать продукт: выявлять и изучать целевую аудиторию, грамотно вкладывать деньги в рекламу, продвигать бренд. Об этом при желании можно найти массу информации, мы же хотим поделиться мнением о перспективах коммерческого проведения уличных квестов. Как правило, в нестоличных городах они не слишком распространены. В Томске нам удалось найти всего одного человека, который специализируется на такого рода деятельности. В остальных случаях проведение на улицах Томска квестов носит эпизодический характер. Речь идет о проведении простых квестов на городских праздниках или, например, квестов, организуемых местными радиостанциями. Но нахождение свободной ниши не всегда означает ее прибыльность: возможно уличные квесты просто не так востребованы, как того бы хотелось. Проработав в пилотном режиме несколько месяцев, мы не возьмемся что-то утверждать на этот счет. Добавим лишь, что заметили спрос на квесты разного рода: как те, что проводятся только в определенных местах города (ими мы и занимались), так и выездные квесты за наказ. В случае последних, речь идет о сопровождении праздников: свадеб, дней рождений и др.

В планах на будущее мы видим расширение ассортимента квестов, а также слияние различных квестовых форм в рамках одной игры: уличных квестов, квесткомнат, книжных квестов и др. У каждого из них есть свои минусы, которые могут 
быть только уравновешены плюсами других форматов [4]. Кроме того, слияние квестовых форм в рамках одной игры сделает ее, безусловно, богаче и увлекательнее.

$$
* * *
$$

1. Мальшакова Е.С. Квест-маршрут как пример инновации в образовательном туризме // Формирование гуманитарной среды в вузе: инновационные образовательные технологии. Компетентностный подход. Пермь, 2017. Т. 1. С. 439-445.

2. Максимова Д.И. Проблема уличного игрового пространства // Научный поиск в современном мире: сборник материалов XII Международной научно-практической конференции. Махачкала, 2016. С. 179-180.

3. Миновская О.В. Городское приключение в воспитании учащейся молодежи: учебно-методическое пособие. Кострома, КГУ им. Н.А. Некрасова, 2012. 128 с.

4. Гурин В.В. Экскурсионный потенциал игровых квестов для школьников // Инновации в науке и практике. Сборник статей по материалам III Международной научно-практической конференции (10 ноября 2017 г., г. Прага). В 4 ч. Ч.4 / - Уфа: Изд. Дендра, 2017. С. 156-162.

\section{Доржеева В.B.}

\section{Административно-правовое положение территорий Российского Северо-Востока} (XVII в. - начало XVIII в. )

Северо-Восточный государственный университет (Россия, Магадан )

doi:10.18411/spc-10-01-2018-11

idsp: 000001:spc-10-01-2018-11

Территориально понятие «Северо-Восток» охватывает тундровые и лесотундровые пространства Чукотского полуострова, лесную зону Приколымья, северное побережье Охотского моря и восточные районы Якутии. Общая площадь около 2 млн. кв. км. В физической географии территория определяется как ЯноЧукотская горная страна, занимающая пространство между реками Леной и Анадырем. Крупнейшие горные системы - цепи Черского, Момский хребет, Лено-Чаунская горная дуга, Чукотское нагорье, горы Чукотского полуострова, средневысотные игоры правого берега реки Колымы.

В современном административно-государственном делении Северо-Восток интегрирует Магаданскую область, Камчатский край, Чукотский автономный округ, северо-восточные районы Республики Якутия (Саха). Магаданская область граничит со всеми указанными субъектами, на юге и юго-востоке омывается водами Охотского моря. Большая часть территории области занято тундрой и лесотундрой. Климат на большей части территории резко континентальный. Вся территория области, исключая побережье, находится в зоне многолетней мерзлоты. Площадь Магаданской области вместе с островами составляет 462,5 тыс. кв. км. Главная водная артерия - река Колыма.

Административно-территориальное деление российского Северо-Востока подвергалось многократным изменениям. Российское государство постепенно продвигало свои границы на восток. Особым в этом процессе стал XVII век. В силу комплекса внешних факторов и социально-экономических причин, сложившихся в России к XVII веку, вокруг страны сформировалось кольцо недружественных государств - Речи Посполитой, Швеции, Турции. Россия оказалась в экономической изоляции, отрезанной от торговых путей и источников торговли. Сама Россия с XVII века вступает в процесс формирования централизованного государства, что сопровождается усилением обмена между областями, ростом товарного обращения, 